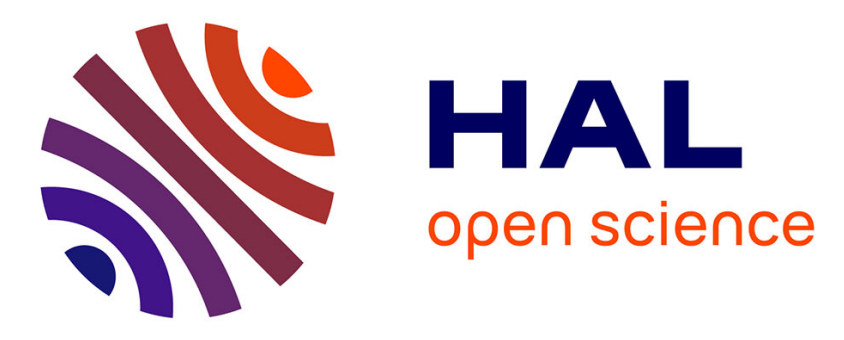

\title{
Synthesis and crystal structure of hexaaquamagnesium hydrogen phosphododecatungstate tetrahydrate $[\mathrm{Mg}(\mathrm{H} 20) 6][\mathrm{HPW} 12040] 4 \mathrm{H} 20$
}

\author{
A. Kremenovic, D. Poleti, Nour-Eddine Ghermani, L. Karanovic, Ubavka
}

Mioč, Z. Nedic, A. Spasojevic-De-Biré

\section{To cite this version:}

A. Kremenovic, D. Poleti, Nour-Eddine Ghermani, L. Karanovic, Ubavka Mioč, et al.. Synthesis and crystal structure of hexaaquamagnesium hydrogen phosphododecatungstate tetrahydrate $[\mathrm{Mg}(\mathrm{H} 20) 6][\mathrm{HPW} 12040] 4 \mathrm{H} 20$. Crystal Research and Technology, 2007, 42 (1), pp.98-104. 10.1002/crat.200610778. hal-00142868

\section{HAL Id: hal-00142868 \\ https://hal.science/hal-00142868}

Submitted on 29 Sep 2020

HAL is a multi-disciplinary open access archive for the deposit and dissemination of scientific research documents, whether they are published or not. The documents may come from teaching and research institutions in France or abroad, or from public or private research centers.
L'archive ouverte pluridisciplinaire HAL, est destinée au dépôt et à la diffusion de documents scientifiques de niveau recherche, publiés ou non, émanant des établissements d'enseignement et de recherche français ou étrangers, des laboratoires publics ou privés. 


\section{Synthesis and crystal structure of hexaaquamagnesium hydrogen phosphododecatungstate tetrahydrate $\left[\mathrm{Mg}\left(\mathrm{H}_{2} \mathrm{O}\right)_{6}\right]\left[\mathrm{HPW}_{12} \mathrm{O}_{40}\right] \cdot 4 \mathrm{H}_{2} \mathrm{O}$}

Aleksandar Kremenovića , Dejan Poletib ${ }^{\mathrm{b}}$, Nour-Eddine Ghermani ${ }^{\mathrm{c}, \mathrm{e}}$, Ljiljana Karanovića ${ }^{\mathrm{a}}$, Ubavka Miočd, Zoran Nedićd and Anne Spasojević-de Birée

${ }^{a}$ Department of Crystallography, Faculty of Mining and Geology, University of Belgrade, Đušina 7, 11000 Belgrade, Serbia and Montenegro

${ }^{b}$ Faculty of Technology and Metallurgy, University of Belgrade, Karnegijeva 4, 11000 Belgrade, Serbia and Montenegro

${ }^{c}$ Laboratoire de Physique Pharmaceutique, UMR CNRS 8612 Faculte de Pharmacie, Universite Paris XI, 5 Rue Jean-Baptiste Clement, 92296 Chatenay-Malabry Cedex, France

${ }^{d}$ Faculty of Physical Chemistry, University of Belgrade, P.O. Box 137, 11001 Belgrade, Serbia and Montenegro

e SPMS, UMR 8580 CNRS Ecole Centrale Paris, 1 Grande Voie des Vignes, 92295 Chatenay-Malabry, France

Corresponding author:

Aleksandar Kremenović

Department of Crystallography

Faculty of Mining and Geology

Đušina 7

11000 Belgrade

Serbia and Montenegro

E-mail: akremen@EUnet.yu

Keywords: Polyoxometalates, Tungsten, Magnesium, Synthesis, Crystal structure, X-ray diffraction. 


\section{Abstract}

Mg-salt of dodecatungstophosphoric acid $\left[\mathrm{Mg}\left(\mathrm{H}_{2} \mathrm{O}\right)_{6}\right]\left[\mathrm{HPW}_{12} \mathrm{O}_{40}\right] \cdot 4 \mathrm{H}_{2} \mathrm{O}$ was prepared by the addition of an equimolar quantity of $\mathrm{Mg}$-chloride aqueous solution into dodecatungstophosphoric acid aqueous solution and slow evaporation of water from mother liquor. This simple synthetic route yielded high quality $\left[\mathrm{Mg}\left(\mathrm{H}_{2} \mathrm{O}\right)_{6}\right]\left[\mathrm{HPW}_{12} \mathrm{O}_{40}\right] \cdot 4 \mathrm{H}_{2} \mathrm{O}$ single crystals. The structure is composed of Keggin, $\left[\mathrm{PW}_{12} \mathrm{O}_{40}\right]^{3-}$ anions, $\left[\mathrm{Mg}\left(\mathrm{H}_{2} \mathrm{O}\right)_{6}\right]^{2+}$ cations and lattice water molecules. Zigzag arrangement of Keggin anions along $c$-axis creates irregular channels occupied by $\left[\mathrm{Mg}\left(\mathrm{H}_{2} \mathrm{O}\right)_{6}\right]^{2+}$ cations and lattice $\mathrm{H}_{2} \mathrm{O}$ molecules. The calculation of total potential solvent area indicated presence of $4 \mathrm{H}_{2} \mathrm{O}$ lattice molecules per formula unit, which is in agreement with here presented structural model. The position of one lattice water molecule is well defined, while the other three molecules are disordered and statistically distributed. Hydrogen bonds involve all coordinated and lattice $\mathrm{H}_{2} \mathrm{O}$ molecules, as well as some oxygens from Keggin anion.

\section{Introduction}

The extensive class of polyoxoanions formed by transition metals of groups 5 and 6 attracts considerable attention in science and technology. As hetero- and isopoly acids or their salts these polyanions have been known and investigated for almost two centuries. In 1826 Berzelius ${ }^{[1]}$ described formation of ammonium 12-molybdophosphate, $\left(\mathrm{NH}_{4}\right)_{3} \mathrm{PMo}_{12} \mathrm{O}_{40}$. However, the true composition of heteropoly acids was not precisely determined until 1862 when tungstosilicic acid was characterized ${ }^{[2]}$. Since then, the interest for investigations on hetero- and isopoly acids and their salts extensively increased ${ }^{[3,4]}$.

Nowadays, heteropoly compounds (HPC) based on Keggin, $\left[\mathrm{XM}_{12} \mathrm{O}_{40}\right]^{\mathrm{n}-}$, structure ${ }^{[5]}$, where $\mathrm{X}$ is a heteroatom $(\mathrm{X}=\mathrm{P}, \mathrm{Si}, \mathrm{Ge}, \ldots)$ and $\mathrm{M}$ is an addenda atom $(\mathrm{W}, \mathrm{Mo}, \ldots)^{[3]}$, have important applications mainly as catalysts. Compatibility of these materials with environmental demands led to their utilization in different reactions ${ }^{[4,6-9]}$. HPC may potentially replace corrosive liquids in acidcatalyzed reactions and can act as photocatalysts in processes of decomposition of environmentally persistent pollutants ${ }^{[10]}$. They are, for example, valuable in removal and conversion of nitrogen oxides [11].

Characteristics of heteropoly acids (HPA) strongly depend on temperature and relative humidity of the surrounding. For some industrial processes it is necessary to have catalysts not sensitive to the surrounding ${ }^{[12-14]}$ and salts of HPA satisfy these conditions. They are more stable and less sensitive to 
humidity and temperature than acids themselves. Moreover, catalytic activities of HPA salts are close to the catalytic activity of HPA ${ }^{[15]}$. While different HPA forms and salts of monovalent cations have received the most attention ${ }^{[13]}$, there are only few reports concerning the catalytic properties of dodecatungstophosphoric (WPA) salts with divalent cations ${ }^{[15-18]}$. It has been shown that Mg salt of WPA (Mg-WPA) is highly active in the conversions of methanol to hydrocarbons ${ }^{[15]}$. Use of acid salts: Zn-WPA, Mg-WPA, Al-WPA, Zr-WPA and B-WPA resulted in high yields of hydrocarbons. The largest concentration of the major product $\mathrm{C}_{4}$ hydrocarbons is produced by the Al-WPA and Mg-WPA. The Al-WPA and Mg-WPA are also the most active in total $\left(\mathrm{C}_{1}\right.$ to $\left.\mathrm{C}_{5}\right)$ hydrocarbon production.

Structures of different hydrates of WPA are still under investigations. Structures of 29, 21 and 6 hydrate were determined long time ago with more or less precision ${ }^{[19-21]}$. The structure of 14-hydrate is not known yet. The structure of Keggin anion, $\left[\mathrm{PW}_{12} \mathrm{O}_{40}\right]^{3-}$, is well-known, but the structure of cationic part, especially when $\mathrm{H}_{2} \mathrm{O}, \mathrm{H}^{+}, \mathrm{H}_{3} \mathrm{O}^{+}, \mathrm{H}_{5} \mathrm{O}_{2}{ }^{+}$, etc. are present, is not precisely defined. According to the equilibrium $\mathrm{H}_{5} \mathrm{O}_{2}{ }^{+} \leftrightarrow \mathrm{H}_{3} \mathrm{O}^{+}+\mathrm{H}_{2} \mathrm{O} \leftrightarrow \mathrm{H}^{+}+2 \mathrm{H}_{2} \mathrm{O}$, in WPA hydrates with 6, 14, 21 and 29 water molecules per formula unit, as well as in their salts, various forms of hydrated proton entities take part in the structure at the same time. This was confirmed by infrared, Raman and IINS techniques ${ }^{[22-25]}$. Structures with precisely defined positions of $\mathrm{H}_{2} \mathrm{O}, \mathrm{H}^{+}, \mathrm{H}_{3} \mathrm{O}^{+}$and $\mathrm{H}_{5} \mathrm{O}_{2}{ }^{+}$are limited to a small number of articles mainly based on neutron diffraction or theoretical calculation ${ }^{[20-21,26-32]}$. Evidently, disorder of protons and water molecules is quite common for HPA compounds.

As already stated, reports of solid 12-tunstophosphoric acid salts containing divalent cations are quite rare ${ }^{[15-18]}$. Such salts are often reported to be of low crystallinity ${ }^{[15]}$ or they have not been formed at all ${ }^{[16]}$. The synthetic procedures were based on the double decomposition method with appropriate hydroxides ${ }^{[16]}$, carbonates ${ }^{[15,17,33]}$ and nitrates ${ }^{[18,33]}$. Therefore, there is a challenge to find a procedure that yields divalent cation WPA salts in a well crystalline form suitable for structural investigation, i.e. in the form of single crystals of a proper quality and dimensions.

The main goals of this work are to present the first successful synthesis of a divalent cation salt of WPA in the single crystal form, to describe its crystal structure including water molecules locations, and to analyze a possible hydrogen-bonding network.

\section{Results and discussion}

Contrary to the application of double decomposition method on appropriate carbonates, nitrates and hydroxides [15-18,33] here described simple synthetic route yielded high quality 
$\left[\mathrm{Mg}\left(\mathrm{H}_{2} \mathrm{O}\right)_{6}\right]\left[\mathrm{HPW}_{12} \mathrm{O}_{40}\right] \cdot 4 \mathrm{H}_{2} \mathrm{O}$ single crystals. Recently, the same synthetic route has successfully been used for the preparation of other alkaline earth salts of WPA in the polycrystalline form ${ }^{[34]}$.

Results of X-ray structure refinement are presented in Tables 1-5. The magnesium salt of tungstophosphoric acid is composed of Keggin anions, $\left[\mathrm{Mg}\left(\mathrm{H}_{2} \mathrm{O}\right)_{6}\right]^{2+}$ cations, and lattice water molecules (Figures 1 and 2). Similar arrangement of polyanions has been noticed in $\mathrm{Mg}_{2} \mathrm{Na}_{2} \mathrm{~V}_{10} \mathrm{O}_{28} \cdot 20 \mathrm{H}_{2} \mathrm{O}$ and $\mathrm{Mg}_{3} \mathrm{~V}_{10} \mathrm{O}_{28} \cdot 28 \mathrm{H}_{2} \mathrm{O}$ [35], as well as in sodium magnesium bis(vanadate) pyrovanadate $\mathrm{Na}_{6} \mathrm{Mg}_{2}\left(\mathrm{VO}_{4}\right)_{2}\left(\mathrm{~V}_{2} \mathrm{O}_{7}\right){ }^{[36]}$.

Previously published ${ }^{[25]}$ preliminary data about magnesium salt of dodecatungstophosphoric acid reported 10 water molecules in the formula unit and presence of hydrated proton species $\left(\mathrm{H}_{3} \mathrm{O}^{+}\right.$ and $\mathrm{H}_{5} \mathrm{O}_{2}{ }^{+}$) in the structure. After reinvestigation using new X-ray diffraction data presence of 10 water molecules was approved, but existence of hydrated proton species was not confirmed. Calculation of total potential solvent area ${ }^{[40]}$ indicated that $652 \AA^{3}$, i.e. $15.6 \%$ of the unit cell volume, could be occupied by lattice $\mathrm{H}_{2} \mathrm{O}$ molecules. Two main voids are located around 00.50 and 000.5 . As a hydrogen bonded $\mathrm{H}_{2} \mathrm{O}$ molecule fills $\approx 40 \AA^{3}$, in total 16.3 lattice $\mathrm{H}_{2} \mathrm{O}$ molecule could be situated in the unit cell, i.e. there could be $4.08 \mathrm{H}_{2} \mathrm{O}$ molecules per formula unit $(Z=4)$. Additional $6 \mathrm{H}_{2} \mathrm{O}$ molecules from the $\left[\mathrm{Mg}\left(\mathrm{H}_{2} \mathrm{O}\right)_{6}\right]^{2+}$ complex gives $10.1 \mathrm{H}_{2} \mathrm{O}$ molecules per formula unit, what is in excellent agreement with our structural model.

The octahedral $\left[\mathrm{Mg}\left(\mathrm{H}_{2} \mathrm{O}\right)_{6}\right]^{2+}$ complex cations and four lattice water molecules are situated in channels surrounded by six Keggin anions (Fig. 2). Position of one lattice water molecule is well defined, while each of three other molecules is statistically distributed over two locations. As expected, proton position was not defined. Hydrogen bonds involve all coordinated and lattice $\mathrm{H}_{2} \mathrm{O}$ molecules, as well as some oxygen atoms from Keggin anion. With three exceptions (Table 5), all hydrogen bonds are longer than $2.8 \AA$ and could be regarded as weak.

In Keggin anion interatomic distances are as expected and unusual short contacts have not been observed ${ }^{[37-38]}$. The inspection of Inorganic Crystal Structure Database (ICSD) ${ }^{[39]}$ showed that for all (20) reported structures containing Keggin anion $\mathrm{W}-\mathrm{O}$ distances vary in a wide range from 1.65 to $2.50 \AA$ as found in the $\left[\mathrm{Mg}\left(\mathrm{H}_{2} \mathrm{O}\right)_{6}\right]\left[\mathrm{HPW}_{12} \mathrm{O}_{40}\right] \cdot 4 \mathrm{H}_{2} \mathrm{O}$. Individual $\mathrm{W}$ atoms are in deformed octahedral environment with equatorial $\mathrm{W}-\mathrm{O}$ bond distances about $1.90 \AA$. One apical $\mathrm{W}-\mathrm{O}$ distance is slightly shorter $(\approx 1.70 \AA)$, while another is much longer $(\approx 2.4 \AA)$, and $\mathrm{W}$ atoms are moved out of the equatorial plane toward closer apex. All O-W-O angles deviate from ideal $90^{\circ}$ and $180^{\circ}$ values for up to $19^{\circ}$ and $6^{\circ}$ each. $\mathrm{O}-\mathrm{W}-\mathrm{O}$ angles that involve shorter apical $\mathrm{W}-\mathrm{O}$ bonds are systematically larger than $90^{\circ}$, while $\mathrm{O}-\mathrm{W}-\mathrm{O}$ angles that involve larger $\mathrm{W}-\mathrm{O}$ bonds are systematically smaller than $90^{\circ}$. Both, $\mathrm{W}-\mathrm{O}$ distances and $\mathrm{O}-\mathrm{W}-\mathrm{O}$ angles indicate that $\mathrm{WO}_{6}$ octahedra are irregular and similar to other Keggin 
structures reported in the ICSD. P-O bonds are between 1.52 and $1.54 \AA$, while $\mathrm{O}-\mathrm{P}-\mathrm{O}$ angles are between 107.6 and $110.7^{\circ}$ (Table 3 ). This is an indication that the $\mathrm{PO}_{4}$ tetrahedra are very close to $T_{d}$ symmetry. Among reported Keggin structures, only in five cases so regular $\mathrm{PO}_{4}$ tetrahedra are observed.

Further inspection of ICSD reveals that 36 structures contain hexaaquamagnesium complex, but only in $19 \mathrm{H}$-atoms are located. In 31 of reported structures $\mathrm{Mg}-\mathrm{O}$ distances are between 2.0 and $2.1 \AA$ as it is for the $\left[\mathrm{Mg}\left(\mathrm{H}_{2} \mathrm{O}\right)_{6}\right]\left[\mathrm{HPW}_{12} \mathrm{O}_{40}\right] \cdot 4 \mathrm{H}_{2} \mathrm{O}$. In all structures, including here reported one, $\mathrm{O}-\mathrm{Mg}-\mathrm{O}$ angles are close to 90 and $180^{\circ}$, indicating very regular octahedral arrangements of $\mathrm{H}_{2} \mathrm{O}$ molecules around $\mathrm{Mg}$ (Table 3).

\section{Experimental}

\subsection{Synthesis and composition of $\left[\mathrm{Mg}\left(\mathrm{H}_{2} \mathrm{O}\right)_{6}\right]\left[\mathrm{HP} W_{12} \mathrm{O}_{40}\right] \cdot 4 \mathrm{H}_{2} \mathrm{O}$}

The Mg-salt of dodecatungstophosphoric acid $\left[\mathrm{Mg}\left(\mathrm{H}_{2} \mathrm{O}\right)_{6}\right]\left[\mathrm{HPW}_{12} \mathrm{O}_{40}\right] \cdot 4 \mathrm{H}_{2} \mathrm{O}$ was prepared by the addition of an equimolar quantity of Mg-chloride aqueous solution into WPA aqueous solution. After slow evaporation of water from mother liquor a salt with 10 water molecules per formula unit was obtained. The Mg-content in the salt was checked by atomic absorption spectrometry (AAS) using a VARIAN AA-775 spectrophotometer. The theoretical Mg content is $0.71 \%$ and the experimentally obtained one was $0.70 \pm 0.03 \%$.

\subsection{Crystal structure determination}

An irregular prismatic crystal was chosen and grinded in an Enraf-Nonius crystal grinder. After about half an hour of grinding the crystal with an ellipsoidal shape $(0.20 \times 0.20 \times 0.15 \mathrm{~mm})$ was obtained. Data were collected at $293 \mathrm{~K}$ on a three axis platform Bruker SMART diffractometer equipped with a $1 \mathrm{~K}$ CCD detector using graphite-monochromated MoK $\alpha$ radiation $(\lambda=0.71703 \AA)$. For data collection the program SMART ${ }^{[41]}$ was used, while unit cell parameters were refined and data were reduced with the program SAINT ${ }^{[41]}$. The structure was solved by direct methods with the SIR97 ${ }^{[42]}$ and refined by the full-matrix least-squares method on $F^{2}$ using the SHELXL-97 [43]. Anisotropic displacement parameters were employed to refine non-hydrogen atoms within Keggin anion and $\left[\mathrm{Mg}\left(\mathrm{H}_{2} \mathrm{O}\right)_{6}\right]^{2+}$ complex cation, as well as the oxygen from ordered lattice water molecule. Isotropic 
displacement parameters of oxygens from three other lattice water molecules were fixed to the value of $0.07 \AA^{2}$.

Attempts to refine occupancy of $\mathrm{O} 48$ and $\mathrm{O} 49$ atoms indicated half occupancy for both $\mathrm{O}$ sites and refinement was finished with these values fixed to 50\% occupancy. These two water molecules are situated close to the special position $2 c$ in space group $P 2_{1} / c$, and they filled up the largest voids in the structure. Having this in mind they can be treated as one water molecule moving from the centre of symmetry and, therefore, distributed in two different general positions, but with half occupancy. The shortest O48-O49 distance is $4.909 \AA$. The other two water sites are split: the shortest distances are $0.923 \AA$ for $\mathrm{O} 50 \mathrm{~A}-\mathrm{O} 50 \mathrm{~B}$ and $1.736 \AA$ for $\mathrm{O} 51 \mathrm{~A}-\mathrm{O} 51 \mathrm{~B}$. Their occupancies were refined as free variables and constrained assuming the full occupancy of each site.

Positions of hydrogen atoms in ordered lattice water molecule, $\mathrm{O} 47$, and $\left[\mathrm{Mg}\left(\mathrm{H}_{2} \mathrm{O}\right)_{6}\right]^{2+}$ complex cations were calculated by the method presented in ${ }^{[44]}$ using the following parameters: Gaussian coefficient 5, $\mathrm{O}-\mathrm{H}$ distance $0.85 \AA$ and charge on $\mathrm{H}$-atoms $0.45 \mathrm{e}^{-}$. The isotropic displacement parameters for generated hydrogens were also fixed to the value of $0.07 \AA^{2}$. Hydrogen atoms for disordered lattice water molecules as well as proton were not located.

The space group and existence of psudomerohedral twinning were also checked. Previously reported ${ }^{[25]}$ space group $P 2{ }_{1} / c$ (No. 14) seams to be true. It was possible to solve and refine the structure in the triclinic space group $P \overline{1}$, but to obtain approximately the same agreement factors of refinement it was necessary to include a twin option. Two twin domains are symmetrically related by

the $180^{\circ}$ rotation around $b$-axes. Together with $\beta$-angle close to $90^{\circ}$, this is an indication for a psudomerohedral twinning in the investigated crystal. Refinement of the twin domain occupancies indicated presence of $50 \%$ for each one, thus simulating $2 / m$ point group symmetry. However, a close inspection of two structure models suggested that the monoclinic model is preferable.

\section{Conclusion}

The first alkaline-earth (magnesium) salt of tungstophosphoric acid single crystal synthesis and its crystal structure are reported. After slow evaporation of water from mother liquor, prepared by the addition of an equimolar quantity of Mg-chloride aqueous solution into WPA aqueous solution, a salt with 10 water molecules per formula unit was obtained. The structure is composed of Keggin anions, $\left[\mathrm{Mg}\left(\mathrm{H}_{2} \mathrm{O}\right)_{6}\right]^{2+}$ cations and water molecules. Hydrogen bonds involve all coordinated and lattice $\mathrm{H}_{2} \mathrm{O}$ molecules, as well as some oxygen atoms from Keggin anion. Most of hydrogen bonds are weak. 


\section{References:}

[1] J. Berzelius, Pogg.Ann. 1826, 6, 369-380.

[2] C. Marignac, C. R. Acad. Sci., 1862, 55, 888.

[3] M.T. Pope, Heteropoly and Isopoly Oxometalates, Springer, Berlin, 1983.

[4] Pope, M.T., Müller, Polyoxometalates: From Platonic Solids to Anti-Retroviral Activity, Kluwer Academic Publishing, London, 1994.

[5] J.F. Keggin, Proceedings of the Royal Society of London, Series A: Mathematical and Physical Sciences 1934, 144, 75-100.

[6] A. Corma, Chem. Rev. 1995, 95, 559-614.

[7] N. Mizuno, M. Misono, Chem. Rev. 1999, 98, 199-218.

[8] C.L. Hill, C.M. Prosser-McCartha, Coord. Chem. Rev. 1995, 143, 407-455.

[9] M. Misono, Chem. Commun. 2001, 1141-1152.

[10] H. Hori, E. Hayakawa, H. Einaga, S. Kutsuna, K. Koike, T. Ibusuki, H. Kiatagawa, R. Arakawa, Environ. Sci. Technol. 2004, 38, 6118-6124.

[11] J.B. Moffat, in: C.A.C. Sequeira and J.B. Moffat (Eds.) Chemistry, Energy and the Enviromental, Royal Society, London, 1998, p. 167.

[12] S. Choi, Y. Wang, Z. Nie, J. Liu, C.H.F. Peden, Catal. Today 2000, 55 (1-2), 117-124.

[13] T. Okuhara, N. Mizuno, M. Misono, Appl. Catal. A: Gen. 2001, 222, 63-77.

[14] E.F. Kozhevnikova, E. Rafiee, I.V. Kozhevnikov, Appl. Catal. A: Gen., 2004, 260, 25-34.

[15] H. Hayashi, J.B. Moffat, J. Catal. 1983, 81, 61-66.

[16] G.B. McGarvey, N.J. Taylor, J.B. Moffat, J. Mol. Catal. 1993, 80, 59-73.

[17] Y. Saito, H. Niiyama, J. Catal. 1987, 106, 329-336.

[18] R. Voyatzis, J.B. Moffat, J. Catal. 1993, 142, 45-58.

[19] J.A. Bradley, J.W. Illingworth, Proceedings of the Royal Society of London, Series A:

Mathematical and Physical Sciences 1936, 157, 113-131.

[20] M.R. Spirlet, W.R. Busing, Acta Cryst. 1978, B34, 907-910.

[21] G.M. Brown, M.R. Noe-Spirlet, W.R. Busing, H.A. Levy, Acta Cryst. 1977, B33, 1038-1046.

[22] U.B. Mioč, Ph. Colomban, M. Davidiović, J. Tomkinson, J. Mol. Struct., 1994, 326, 99-107.

[23] U.B. Mioč, R.Ž. Dimitrijević, M. Davidović, Z.P. Nedić, M.M. Mitrović, Ph. Colomban, J. Mater.

Sci. 1994, 29, 3705-3718.

[24] U.B. Mioč, M. Davidović, N. Tjapkin, Ph. Colomban, Solid State Ionics 1992, 46, 103-109. 
[25] U.B. Mioč, M.R. Todorović, S.M. Uskoković-Marković, A. Kremenović, A. Spasojvić-de Biré, T. Čajkovski, V. Likar-Smiljanić, R. Biljić, Solid State Ionics 2003, 162-163, 217-223.

[26] G.A. Jeffrey, An Introduction to Hydrogen Bonding, Oxford Univ. Press, New York, 1997.

[27] J.O. Lundgren, R. Tellgren, Acta Cryst. 1974, B30, 1937-1947.

[28] F.A. Cotton, C.K. Fair, G.E. Lewis, G.N. Mott, F.K. Ross, A.J. Schultz, J.M. Williams, J. Am.

Chem. Soc. 1984, 106, 5319-5323.

[29] R. Attig, J.M. Williams, Angew. Chem. Ger. Ed. 1976, 88, 507-508.

[30] G.D. Brunton, C.G. Johanson, J.Chem.Phys. 1975, 62, 3797-3806.

[31] D. Marx, M.E. Tuckerman, J. Hutter, M. Parrinello, Nature 1999, 397, 601-604.

[32] F.F. Muguet, J. Mol. Struct. (Teochem) 1996, 368, 173-196.

[33] G. Koyano, K. Ueno, M. Misono, Appl. Catal. A: Gen. 1999, 181, 267-275.

[34] Lj. Damljanović, V. Rakić, U.B. Mioč, A. Auroux, Thermochimica Acta 2005, 434, 81-87.

[35] A. Iida, T. Ozeki, Acta Cryst. 2004, C60, i43-i46

[36] A. Mitiaev, A. Mironov, R. Shpanchenko, E. Antipov, Acta Cryst. 2004, C60, i56-i58

[37] M. Nardelli, Comput. Chem. 1983, 7, 95-98.

[38] M. Nardelli, J. Appl. Cryst. 1995, 28, 659.

[39] D. Altermatt, I.D. Brown, Acta Cryst. 1985, B41, 240-244.

[40] A.L. Spek, Acta Cryst. 1990, A46, C34

[41] SADABS, SMART and SAINT: Siemens Industrial Automation, Inc., Madison, 1995

[42] A. Altomare, G. Cascarano, C. Giacovazzo, A. Guagliardi, J. Appl. Cryst. 1993, 26, 343-350.

[43] G.M. Sheldrick, SHELXL97, Program for crystal structure refinement. University of Göttingen, Germany, 1997.

[44] M. Nardelli, J. Appl. Cryst. 1999, 32, 563-571.

[45] L.J. Farrugia, ORTEP-3 for Windows, J. Appl. Cryst. 1997, 30, 565. 
Figure 1. Asymmetric unit of $\left[\mathrm{Mg}\left(\mathrm{H}_{2} \mathrm{O}\right)_{6}\right]\left[\mathrm{HPW}_{12} \mathrm{O}_{40}\right] \cdot 4 \mathrm{H}_{2} \mathrm{O}$ with $50 \%$ probability displacement ellipsoids (Ortep-3 for Windows ${ }^{[45]}$ ).

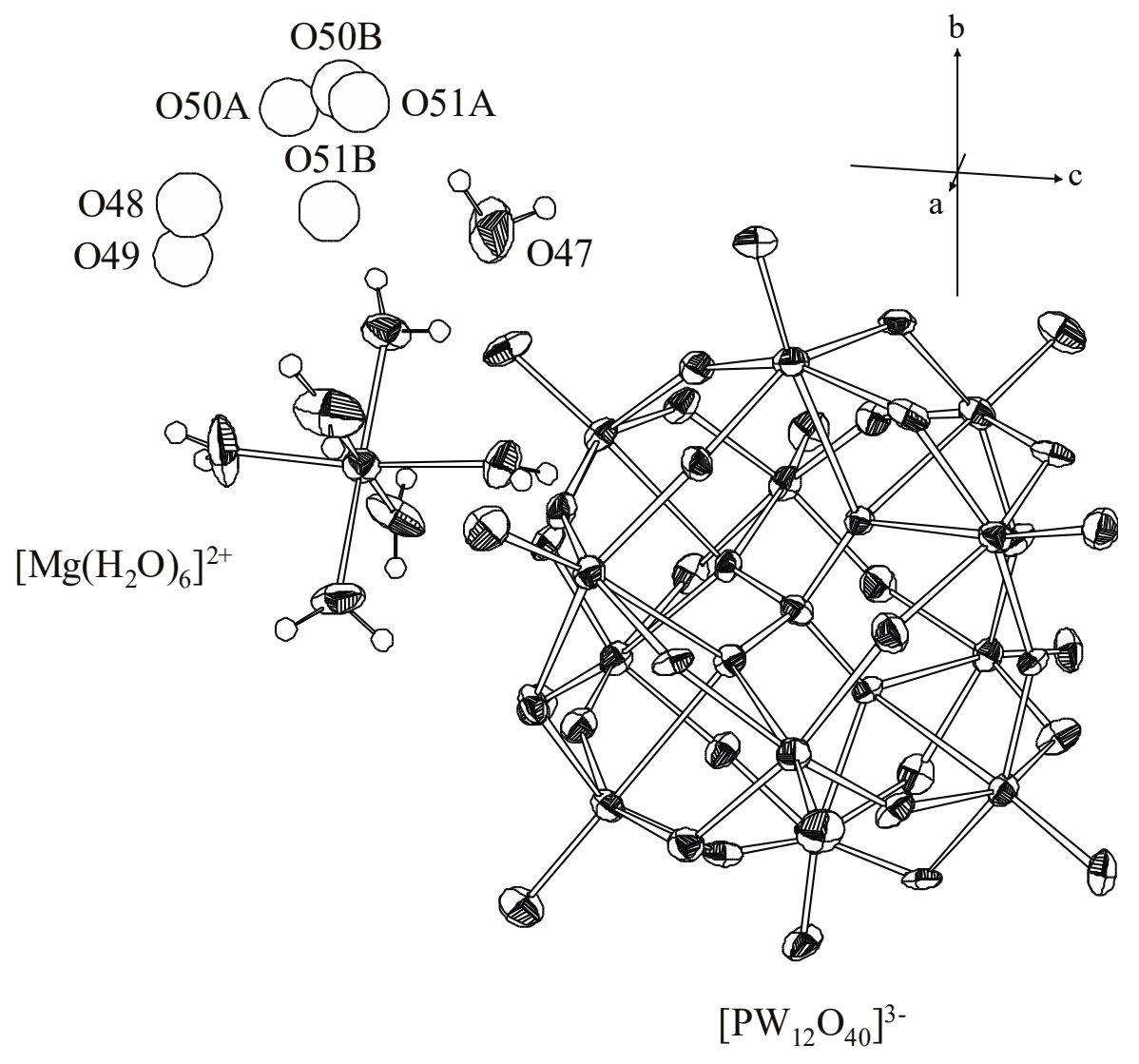


Figure 2. Packing of $\left[\mathrm{Mg}\left(\mathrm{H}_{2} \mathrm{O}\right)_{6}\right]\left[\mathrm{HPW}_{12} \mathrm{O}_{40}\right] \cdot 4 \mathrm{H}_{2} \mathrm{O}$ with $50 \%$ probability displacement ellipsoids (Ortep-3 for Windows ${ }^{[45]}$ ).

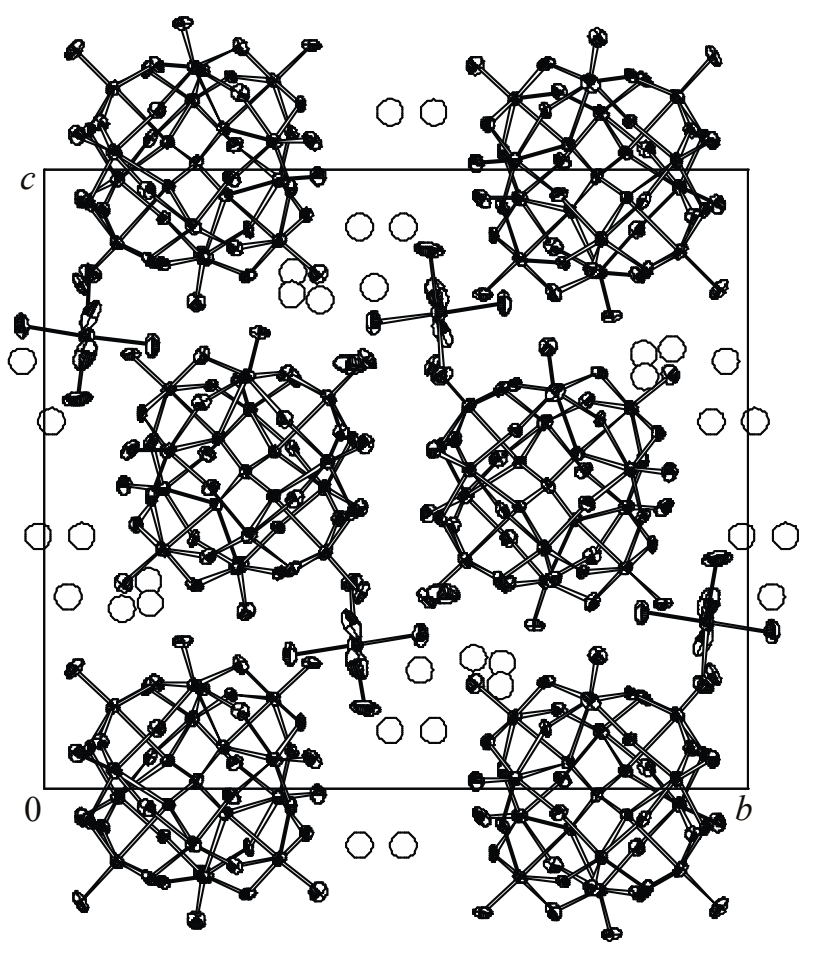




\section{Table captions}

Table 1. Crystal data and results of structure refinement for $\left[\mathrm{Mg}\left(\mathrm{H}_{2} \mathrm{O}\right)_{6}\right]\left[\mathrm{HPW}_{12} \mathrm{O}_{40}\right] \cdot 4 \mathrm{H}_{2} \mathrm{O}$.

Table 2. Atomic coordinates and equivalent isotropic displacement parameters $\left(\AA^{2}\right)$ for $\left[\mathrm{Mg}\left(\mathrm{H}_{2} \mathrm{O}\right)_{6}\right]\left[\mathrm{HPW}_{12} \mathrm{O}_{40}\right] \cdot 4 \mathrm{H}_{2} \mathrm{O} . U_{\text {eq }}$ is defined as one third of the trace of the orthogonalized $U_{\mathrm{ij}}$ tensor. S.O.F. is a site occupation factor.

Table 3. Selected bond lengths $[\AA]$ and angles $\left[^{\circ}\right]$ for $\left[\mathrm{Mg}\left(\mathrm{H}_{2} \mathrm{O}\right)_{6}\right]\left[\mathrm{HPW}_{12} \mathrm{O}_{40}\right] \cdot 4 \mathrm{H}_{2} \mathrm{O}$.

Table 4. Hydrogen coordinates for $\left[\mathrm{Mg}\left(\mathrm{H}_{2} \mathrm{O}\right)_{6}\right]\left[\mathrm{HPW}_{12} \mathrm{O}_{40}\right] \cdot 4 \mathrm{H}_{2} \mathrm{O}$.

Table 5. Potential hydrogen bonds $\left[\AA\right.$ and $\left.{ }^{\circ}\right]$ between: (a) oxygens from Keggin anions and $\left[\mathrm{Mg}\left(\mathrm{H}_{2} \mathrm{O}\right)_{6}\right]^{2+}$ complex, (b) oxygens from Keggin anion and lattice $\mathrm{H}_{2} \mathrm{O}$ molecules, (c) oxygens from $\left[\mathrm{Mg}\left(\mathrm{H}_{2} \mathrm{O}\right)_{6}\right]^{2+}$ complex and lattice $\mathrm{H}_{2} \mathrm{O}$ molecules, (d) oxygens from lattice $\mathrm{H}_{2} \mathrm{O}$ molecules. 
Table 1. Crystal data and results of structure refinement for $\left[\mathrm{Mg}\left(\mathrm{H}_{2} \mathrm{O}\right)_{6}\right]\left[\mathrm{HPW}_{12} \mathrm{O}_{40}\right] \cdot 4 \mathrm{H}_{2} \mathrm{O}$.

\begin{tabular}{|c|c|}
\hline Empirical formula & $\mathrm{H}_{21} \mathrm{MgO}_{50} \mathrm{PW}_{12}$ \\
\hline Formula weight & 3082.65 \\
\hline Temperature $[\mathrm{K}]$ & $293(2)$ \\
\hline Wavelength $[\AA]$ & 0.71073 \\
\hline Crystal system, space group & monoclinic, $P 2_{1} / c$ (no. 14$)$ \\
\hline \multirow[t]{4}{*}{ Unit cell dimensions $\left[\AA\right.$ and $\left.^{\circ}\right]$} & $a=9.868(6)$ \\
\hline & $b=21.980(10)$ \\
\hline & $c=19.289(10)$ \\
\hline & $\beta=90.630(5)$ \\
\hline Cell volume $\left[\AA^{3}\right]$ & $4184(4)$ \\
\hline$Z$, Calculated density $\left[\mathrm{g} / \mathrm{cm}^{3}\right]$ & $4,4.894$ \\
\hline Absorption coefficient $\left[\mathrm{mm}^{-1}\right]$ & 33.026 \\
\hline$F(000)$ & 5344 \\
\hline Crystal size $[\mathrm{mm}]$ & $0.20 \times 0.20 \times 0.15$ \\
\hline$\theta$-range for data collection $\left[{ }^{\circ}\right]$ & 1.40 to 28.28 \\
\hline Limiting indices & $-13 \leq h \leq 13,-28 \leq k \leq 29,-24 \leq l \leq 25$ \\
\hline Reflections collected / unique & $83177 / 10301\left[R_{\text {int }}=0.0385\right]$ \\
\hline Completeness to $\theta=28.28^{\circ}$ & $99.3 \%$ \\
\hline Absorption correction & Multiscan (SADABS ${ }^{[41]}$ ) \\
\hline Max. and min. transmission & 0.0830 and 0.0581 \\
\hline Refinement method & Full-matrix least-squares on $F^{2}$ \\
\hline Data / parameters & $10301 / 571$ \\
\hline Goodness-of-fit on $F^{2}$ & 1.490 \\
\hline Final $R$ indices $[I>2 \sigma(I)]$ & $R_{1}=0.0576, w R_{2}=0.1059$ \\
\hline$R$ indices (all data) & $R_{1}=0.0591, w R_{2}=0.1063$ \\
\hline Extinction coefficient & $0.000141(6)$ \\
\hline Largest diff. peak and hole $\left[\mathrm{e}^{-3}\right]$ & 3.00 and -3.77 \\
\hline
\end{tabular}


Table 2. Atomic coordinates and equivalent isotropic displacement parameters $\left(\AA^{2}\right)$ for $\left[\mathrm{Mg}\left(\mathrm{H}_{2} \mathrm{O}\right)_{6}\right]\left[\mathrm{HPW}_{12} \mathrm{O}_{40}\right] \cdot 4 \mathrm{H}_{2} \mathrm{O} . U_{\text {eq }}$ is defined as one third of the trace of the orthogonalized $U_{\mathrm{ij}}$ tensor.

S.O.F. is a site occupation factor.

\begin{tabular}{|c|c|c|c|c|c|}
\hline Atom & $x$ & $y$ & $z$ & $U_{\text {eq }}$ & S.O.F. \\
\hline $\mathrm{W}(1)$ & $0.1649(1)$ & $0.1674(1)$ & $0.3856(1)$ & $0.019(1)$ & 1 \\
\hline $\mathrm{W}(2)$ & $0.0583(1)$ & $0.4030(1)$ & $0.6318(1)$ & $0.020(1)$ & 1 \\
\hline $\mathrm{W}(3)$ & $-0.1208(1)$ & $0.1680(1)$ & $0.4843(1)$ & $0.017(1)$ & 1 \\
\hline$W(4)$ & $0.3717(1)$ & $0.4018(1)$ & $0.5278(1)$ & $0.020(1)$ & 1 \\
\hline$W(5)$ & $-0.1380(1)$ & $0.3971(1)$ & $0.4851(1)$ & $0.018(1)$ & 1 \\
\hline $\mathrm{W}(6)$ & $-0.1781(1)$ & $0.2906(1)$ & $0.6119(1)$ & $0.017(1)$ & 1 \\
\hline$W(7)$ & $0.3225(1)$ & $0.2873(1)$ & $0.6658(1)$ & $0.019(1)$ & 1 \\
\hline $\mathrm{W}(8)$ & $0.1749(1)$ & $0.3981(1)$ & $0.3815(1)$ & $0.019(1)$ & 1 \\
\hline $\mathrm{W}(9)$ & $0.3744(1)$ & $0.1746(1)$ & $0.5459(1)$ & $0.019(1)$ & 1 \\
\hline $\mathrm{W}(10)$ & $-0.0774(1)$ & $0.2752(1)$ & $0.3574(1)$ & $0.017(1)$ & 1 \\
\hline $\mathrm{W}(11)$ & $0.0883(1)$ & $0.1752(1)$ & $0.6445(1)$ & $0.017(1)$ & 1 \\
\hline $\mathrm{W}(12)$ & $0.4197(1)$ & $0.2894(1)$ & $0.4084(1)$ & $0.021(1)$ & 1 \\
\hline $\mathrm{P}$ & $0.1229(4)$ & $0.2848(2)$ & $0.5111(2)$ & $0.018(1)$ & 1 \\
\hline $\mathrm{O}(1)$ & $-0.1779(11)$ & $0.2113(5)$ & $0.4034(6)$ & $0.021(2)$ & 1 \\
\hline $\mathrm{O}(2)$ & $-0.1938(12)$ & $0.2303(5)$ & $0.5402(6)$ & $0.024(2)$ & 1 \\
\hline $\mathrm{O}(3)$ & $-0.0924(11)$ & $0.3549(5)$ & $0.6629(6)$ & $0.021(2)$ & 1 \\
\hline $\mathrm{O}(4)$ & $0.3300(12)$ & $0.3512(5)$ & $0.3539(6)$ & $0.024(2)$ & 1 \\
\hline $\mathrm{O}(5)$ & $0.0131(11)$ & $0.1293(5)$ & $0.4261(6)$ & $0.020(2)$ & 1 \\
\hline $\mathrm{O}(6)$ & $0.2082(11)$ & $0.2227(5)$ & $0.6994(6)$ & $0.024(2)$ & 1 \\
\hline $\mathrm{O}(7)$ & $0.3939(12)$ & $0.3408(6)$ & $0.5964(6)$ & $0.026(2)$ & 1 \\
\hline $\mathrm{O}(8)$ & $0.2212(12)$ & $0.1118(6)$ & $0.3314(7)$ & $0.030(3)$ & 1 \\
\hline $\mathrm{O}(9)$ & $0.2623(11)$ & $0.1507(5)$ & $0.4705(6)$ & $0.021(2)$ & 1 \\
\hline $\mathrm{O}(10)$ & $0.0655(11)$ & $0.3325(5)$ & $0.3477(5)$ & $0.019(2)$ & 1 \\
\hline $\mathrm{O}(11)$ & $-0.2431(10)$ & $0.3507(5)$ & $0.5503(6)$ & $0.018(2)$ & 1 \\
\hline $\mathrm{O}(12)$ & $0.0429(11)$ & $0.2122(5)$ & $0.3282(5)$ & $0.020(2)$ & 1 \\
\hline $\mathrm{O}(13)$ & $0.2462(11)$ & $0.1370(5)$ & $0.6061(6)$ & $0.019(2)$ & 1 \\
\hline $\mathrm{O}(14)$ & $0.0523(10)$ & $0.2433(5)$ & $0.4590(5)$ & $0.016(2)$ & 1 \\
\hline $\mathrm{O}(15)$ & $-0.3142(12)$ & $0.2777(5)$ & $0.6621(6)$ & $0.024(2)$ & 1 \\
\hline $\mathrm{O}(16)$ & $-0.0617(12)$ & $0.4375(5)$ & $0.5646(6)$ & $0.021(2)$ & 1 \\
\hline $\mathrm{O}(17)$ & $0.0226(11)$ & $0.4180(5)$ & $0.4360(6)$ & $0.021(2)$ & 1 \\
\hline $\mathrm{O}(18)$ & $-0.2386(12)$ & $0.1124(5)$ & $0.4893(7)$ & $0.028(3)$ & 1 \\
\hline $\mathrm{O}(19)$ & $0.1755(11)$ & $0.3414(5)$ & $0.6708(6)$ & $0.023(2)$ & 1 \\
\hline $\mathrm{O}(20)$ & $0.2257(10)$ & $0.3251(5)$ & $0.4730(5)$ & $0.015(2)$ & 1 \\
\hline $\mathrm{O}(21)$ & $0.4395(11)$ & $0.2351(5)$ & $0.4860(6)$ & $0.023(2)$ & 1 \\
\hline $\mathrm{O}(22)$ & $0.2073(12)$ & $0.4212(5)$ & $0.5752(6)$ & $0.025(2)$ & 1 \\
\hline $\mathrm{O}(23)$ & $0.4275(10)$ & $0.2223(5)$ & $0.6242(6)$ & $0.023(2)$ & 1 \\
\hline $\mathrm{O}(24)$ & $0.2950(11)$ & $0.2308(5)$ & $0.3741(6)$ & $0.023(2)$ & 1 \\
\hline $\mathrm{O}(25)$ & $-0.1531(11)$ & $0.3311(5)$ & $0.4217(5)$ & $0.018(2)$ & 1 \\
\hline $\mathrm{O}(26)$ & $0.2904(12)$ & $0.4376(5)$ & $0.4463(6)$ & $0.023(2)$ & 1 \\
\hline $\mathrm{O}(27)$ & $0.4973(12)$ & $0.1205(6)$ & $0.5467(7)$ & $0.030(3)$ & 1 \\
\hline $\mathrm{O}(28)$ & $-0.0070(11)$ & $0.1506(5)$ & $0.5608(6)$ & $0.021(2)$ & 1 \\
\hline $\mathrm{O}(29)$ & $0.4800(11)$ & $0.3552(6)$ & $0.4673(6)$ & $0.024(2)$ & 1 \\
\hline
\end{tabular}




\begin{tabular}{lrrrrr}
$\mathrm{O}(30)$ & $0.1682(13)$ & $0.4498(6)$ & $0.3158(7)$ & $0.032(3)$ & 1 \\
$\mathrm{O}(31)$ & $0.0165(10)$ & $0.3259(5)$ & $0.5444(5)$ & $0.015(2)$ & 1 \\
$\mathrm{O}(32)$ & $0.5598(12)$ & $0.2752(6)$ & $0.3603(7)$ & $0.030(3)$ & 1 \\
$\mathrm{O}(33)$ & $0.4822(12)$ & $0.4551(6)$ & $0.5562(7)$ & $0.029(3)$ & 1 \\
$\mathrm{O}(34)$ & $0.0654(13)$ & $0.4581(6)$ & $0.6937(7)$ & $0.032(3)$ & 1 \\
$\mathrm{O}(35)$ & $-0.1724(12)$ & $0.2853(6)$ & $0.2861(7)$ & $0.029(3)$ & 1 \\
$\mathrm{O}(36)$ & $0.1965(10)$ & $0.2465(4)$ & $0.5663(5)$ & $0.014(2)$ & 1 \\
$\mathrm{O}(37)$ & $-0.0426(12)$ & $0.2361(5)$ & $0.6510(5)$ & $0.021(2)$ & 1 \\
$\mathrm{O}(38)$ & $0.4175(12)$ & $0.3048(6)$ & $0.7367(6)$ & $0.028(3)$ & 1 \\
$\mathrm{O}(39)$ & $-0.2525(13)$ & $0.4480(5)$ & $0.4527(7)$ & $0.029(3)$ & 1 \\
$\mathrm{O}(40)$ & $0.0344(12)$ & $0.1218(6)$ & $0.7019(6)$ & $0.026(2)$ & 1 \\
$\mathrm{Mg}$ & $0.6166(6)$ & $0.4404(3)$ & $0.2312(3)$ & $0.027(1)$ & 1 \\
$\mathrm{O}(41)$ & $0.6107(17)$ & $0.3479(6)$ & $0.2158(9)$ & $0.047(4)$ & 1 \\
$\mathrm{O}(42)$ & $0.5569(15)$ & $0.4358(7)$ & $0.3329(7)$ & $0.038(3)$ & 1 \\
$\mathrm{O}(43)$ & $0.4154(18)$ & $0.4433(8)$ & $0.2007(11)$ & $0.065(6)$ & 1 \\
$\mathrm{O}(44)$ & $0.6129(16)$ & $0.5334(6)$ & $0.2473(8)$ & $0.043(4)$ & 1 \\
$\mathrm{O}(45)$ & $0.6700(20)$ & $0.4548(10)$ & $0.1293(8)$ & $0.071(6)$ & 1 \\
$\mathrm{O}(46)$ & $0.8114(13)$ & $0.4355(7)$ & $0.2644(9)$ & $0.046(4)$ & 1 \\
$\mathrm{O}(47)$ & $0.3780(20)$ & $0.5657(11)$ & $0.3143(9)$ & $0.070(6)$ & 1 \\
$\mathrm{O}(48)$ & $0.0620(40)$ & $0.5094(19)$ & $0.9070(20)$ & 0.070 & 0.5 \\
$\mathrm{O}(49)$ & $0.4600(40)$ & $0.5527(19)$ & $0.0920(20)$ & 0.070 & 0.5 \\
$\mathrm{O}(50 \mathrm{~A})$ & $0.3940(40)$ & $0.6475(16)$ & $0.1650(20)$ & 0.070 & $0.61(4)$ \\
$\mathrm{O}(50 \mathrm{~B})$ & $0.3330(60)$ & $0.6490(30)$ & $0.2010(30)$ & 0.070 & $0.39(4)$ \\
$\mathrm{O}(51 \mathrm{~A})$ & $0.1760(50)$ & $0.6090(20)$ & $0.2100(30)$ & 0.070 & $0.42(3)$ \\
$\mathrm{O}(51 \mathrm{~B})$ & $0.1600(40)$ & $0.5325(17)$ & $0.1905(19)$ & 0.070 & $0.58(3)$ \\
\hline
\end{tabular}


Table 3. Selected bond lengths $[\AA]$ and angles $\left[^{\circ}\right]$ for $\left[\mathrm{Mg}\left(\mathrm{H}_{2} \mathrm{O}\right)_{6}\right]\left[\mathrm{HPW}_{12} \mathrm{O}_{40}\right] \cdot 4 \mathrm{H}_{2} \mathrm{O}$.

\begin{tabular}{lc}
\hline \multicolumn{2}{c}{ Around P atom } \\
$\mathrm{P}-\mathrm{O}(14)$ & $1.520(10)$ \\
$\mathrm{P}-\mathrm{O}(31)$ & $1.532(11)$ \\
$\mathrm{P}-\mathrm{O}(36)$ & $1.533(10)$ \\
$\mathrm{P}-\mathrm{O}(20)$ & $1.540(10)$ \\
$\mathrm{O}(14)-\mathrm{P}-\mathrm{O}(31)$ & $108.6(6)$ \\
$\mathrm{O}(14)-\mathrm{P}-\mathrm{O}(36)$ & $109.9(6)$ \\
$\mathrm{O}(31)-\mathrm{P}-\mathrm{O}(36)$ & $110.7(6)$ \\
$\mathrm{O}(14)-\mathrm{P}-\mathrm{O}(20)$ & $109.2(6)$ \\
$\mathrm{O}(31)-\mathrm{P}-\mathrm{O}(20)$ & $108.6(6)$ \\
$\mathrm{O}(36)-\mathrm{P}-\mathrm{O}(20)$ & $109.7(6)$ \\
& \\
$\mathrm{Mg}-\mathrm{O}(46)$ & $2.021(15)$ \\
$\mathrm{Mg}-\mathrm{O}(41)$ & $2.056(15)$ \\
$\mathrm{Mg}-\mathrm{O}(42)$ & $2.057(15)$ \\
$\mathrm{Mg}-\mathrm{O}(45)$ & $2.064(17)$ \\
$\mathrm{Mg}-\mathrm{O}(43)$ & $2.066(18)$ \\
$\mathrm{Mg}-\mathrm{O}(44)$ & $2.067(15)$ \\
$\mathrm{O}(46)-\mathrm{Mg}-\mathrm{O}(41)$ & $91.1(6)$ \\
$\mathrm{O}(46)-\mathrm{Mg}-\mathrm{O}(42)$ & $88.7(7)$ \\
$\mathrm{O}(41)-\mathrm{Mg}-\mathrm{O}(42)$ & $94.6(7)$ \\
$\mathrm{O}(46)-\mathrm{Mg}-\mathrm{O}(45)$ & $93.3(9)$ \\
$\mathrm{O}(41)-\mathrm{Mg}-\mathrm{O}(45)$ & $91.2(8)$ \\
$\mathrm{O}(42)-\mathrm{Mg}-\mathrm{O}(45)$ & $173.8(8)$ \\
$\mathrm{O}(46)-\mathrm{Mg}-\mathrm{O}(43)$ & $177.7(9)$ \\
$\mathrm{O}(41)-\mathrm{Mg}-\mathrm{O}(43)$ & $87.9(7)$ \\
$\mathrm{O}(42)-\mathrm{Mg}-\mathrm{O}(43)$ & $89.3(8)$ \\
$\mathrm{O}(45)-\mathrm{Mg}-\mathrm{O}(43)$ & $88.8(9)$ \\
$\mathrm{O}(46)-\mathrm{Mg}-\mathrm{O}(44)$ & $91.3(7)$ \\
$\mathrm{O}(41)-\mathrm{Mg}-\mathrm{O}(44)$ & $84.3(6)$ \\
$\mathrm{O}(42)-\mathrm{Mg}-\mathrm{O}(44)$ & $89.8(8)$ \\
$\mathrm{O}(45)-\mathrm{Mg}-\mathrm{O}(44)$ & \\
$\mathrm{O}(43)-\mathrm{Mg}-\mathrm{O}(44)$ & \\
\hline & \\
& \\
& \\
& \\
& \\
&
\end{tabular}


Table 4. Hydrogen coordinates for $\left[\mathrm{Mg}\left(\mathrm{H}_{2} \mathrm{O}\right)_{6}\right]\left[\mathrm{HPW}_{12} \mathrm{O}_{40}\right] \cdot 4 \mathrm{H}_{2} \mathrm{O}$.

\begin{tabular}{lrrr}
\hline Atom & $x$ & $y$ & $z$ \\
\hline H411 & 0.6142 & 0.3268 & 0.1785 \\
H412 & 0.6255 & 0.3233 & 0.2493 \\
H421 & 0.4870 & 0.4148 & 0.3436 \\
H422 & 0.6066 & 0.4380 & 0.3692 \\
H431 & 0.3633 & 0.4120 & 0.2031 \\
H432 & 0.3773 & 0.4676 & 0.1715 \\
H441 & 0.6171 & 0.5713 & 0.2391 \\
H442 & 0.5719 & 0.5288 & 0.2856 \\
H451 & 0.6197 & 0.4584 & 0.0932 \\
H452 & 0.7520 & 0.4604 & 0.1158 \\
H461 & 0.8700 & 0.4067 & 0.2673 \\
H462 & 0.8538 & 0.4686 & 0.2732 \\
H471 & 0.3848 & 0.5841 & 0.3537 \\
H472 & 0.3292 & 0.5894 & 0.2884 \\
\hline
\end{tabular}


Table 5. Potential hydrogen bonds $\left[\AA\right.$ and $\left.^{\circ}\right]$ between: (a) oxygens from Keggin anions and $\left[\mathrm{Mg}\left(\mathrm{H}_{2} \mathrm{O}\right)_{6}\right]^{2+}$ complex, (b) oxygens from Keggin anion and lattice $\mathrm{H}_{2} \mathrm{O}$ molecules, (c) oxygens from $\left[\mathrm{Mg}\left(\mathrm{H}_{2} \mathrm{O}\right)_{6}\right]^{2+}$ complex and lattice $\mathrm{H}_{2} \mathrm{O}$ molecules, (d) oxygens from lattice $\mathrm{H}_{2} \mathrm{O}$ molecules.

\begin{tabular}{|c|c|c|c|c|}
\hline D-H...A & $\mathrm{d}(\mathrm{D}-\mathrm{H})$ & $\mathrm{d}(\mathrm{H} \ldots \mathrm{A})$ & $\mathrm{d}(\mathrm{D} \ldots \mathrm{A})$ & $<(\mathrm{DHA})$ \\
\hline \multicolumn{5}{|l|}{ (a) } \\
\hline $\mathrm{O} 41-\mathrm{H} 411 \ldots \mathrm{O} 23$ & 0.86 & 2.37 & $2.95(2)$ & 125 \\
\hline O41-H411...O15 & 0.86 & 2.43 & $3.04(2)$ & 129 \\
\hline O41-H412...O35 & 0.86 & 2.27 & $2.87(2)$ & 128 \\
\hline O42-H421...O4 & 0.86 & 2.10 & $2.94(2)$ & 168 \\
\hline O42-H422...O39 & 0.85 & 2.13 & $2.98(2)$ & 174 \\
\hline O43-H431...O13 & 0.86 & 2.44 & $3.03(2)$ & 126 \\
\hline O44-H441...O8 & 0.85 & 2.29 & $2.83(2)$ & 122 \\
\hline O45-H451...O27 & 0.86 & 2.29 & $2.85(2)$ & 123 \\
\hline O46-H461...O40 & 0.86 & 2.16 & $2.82(2)$ & 133 \\
\hline $\begin{array}{l}\mathrm{O} 46-\mathrm{H} 462 \ldots \mathrm{O} 34 \\
\text { (b) }\end{array}$ & \multicolumn{3}{|c|}{ (b) } & 171 \\
\hline O47-H471...O33 & 0.86 & 2.33 & $2.88(2)$ & 122 \\
\hline $\mathrm{O} 48-* \ldots \mathrm{O} 5$ & & & $3.11(4)$ & \\
\hline O49-*...O18 & & & $2.98(4)$ & \\
\hline O49-*...O27 & & & $3.10(4)$ & \\
\hline O50A-*...O1 & & & $2.87(4)$ & \\
\hline $\mathrm{O} 50 \mathrm{~A}-* \ldots \mathrm{O} 32$ & & & $2.89(4)$ & \\
\hline $\mathrm{O} 50 \mathrm{~A}-* \ldots \mathrm{O} 38$ & & & $2.83(4)$ & \\
\hline O50B-*...O1 & & & $2.87(6)$ & \\
\hline $\mathrm{O} 50 \mathrm{~B}-* \ldots \mathrm{O} 32$ & & & $3.19(6)$ & \\
\hline $\mathrm{O} 50 \mathrm{~B}-* \ldots \mathrm{O} 38$ & & & $2.90(6)$ & \\
\hline O51A-*...O1 & & & $3.13(5)$ & \\
\hline $\mathrm{O} 51 \mathrm{~A}-* \ldots \mathrm{O} 3$ & & & $2.71(5)$ & \\
\hline O51B-*...O34 & & & $3.17(4)$ & \\
\hline \multicolumn{5}{|l|}{ (c) } \\
\hline O45-H452...O48 & 0.86 & 2.00 & $2.85(5)$ & 168 \\
\hline O45-H451...O49 & 0.86 & 2.60 & $3.07(5)$ & 115 \\
\hline O44-H442...O47 & 0.85 & 2.16 & $2.76(2)$ & 126 \\
\hline $\begin{array}{l}\mathrm{O} 43-\mathrm{H} 432 \ldots \mathrm{O} 51 \mathrm{~B} \\
\text { (d) }\end{array}$ & 0.86 & 2.61 & $3.20(4)$ & 127 \\
\hline O47-H472...O50B & 0.86 & 2.14 & $2.88(6)$ & 144 \\
\hline O47-H472...O51A & 0.86 & 2.17 & $2.97(5)$ & 155 \\
\hline O51B-*...O48 & & & $3.02(6)$ & \\
\hline
\end{tabular}

$* \mathrm{H}$-atoms are not located 